\title{
REVISION OF THE LITERARY CANON: THE AMERICAN EXPERIENCE
}

\author{
G. Thomas Couser
}

RESUMO:

PALAVRAS-CHAVE:

The process of revising the American literary canon is now a couple of decades old. Recently, the controversy over canon revision has become a more public issue - that is, a matter of concern outside the academy. In what follows, I describe some of the changes over the last thirty years, suggest some of the forces behind the changes, and explore some reasons why it has become controversial.

I mean the term canon to refer to the official canon, that institutionalized by education and criticism - what we sometimes refer to as the classics or the tradition. Those terms refer to the set of literary works that are said to have passed the test of time, to have been adjudged as having lasting value and permanent status within a particular culture - in this case, the national culture of the U.S. In practice, the canon is what is anthologized; not all that is anthologized gets taught, of course, but almost_nothing that isn't anthologized gets taught. Anthologies are important because they make available for teaching — and place compactly in students' hands — the texts considered worthy of attention.

Perhaps, as a scholar whose specialty is the study of autobiography, I may be forgiven approaching my topic by way of autobiography. I began college about 30 years ago, and over the last three decades, as student and teacher, I have witnessed and participated in the process of the revision of the literary canon in the U.S. I can assure you that the canon I studied as an undergraduate in the late $1960 \mathrm{~s}$ is dramatically different from that my students now read in the late 1990s.

Let me chart the revision of the literary canon over the last several decades by citing three moments in my education from the 1960 s to the present. In the first moment, I was still an amateur - an undergraduate specializing in English (which in the U.S. means the study of British and

Hofstra University, EUA. 
American literature). As it happens, I was, even then, especially interested in American literature, and I remember the canon I was introduced to then as being very narrow, very selective. Little attention, if any, was paid, to the colonial or prerevolutionary period. Aside from a few early figures like Benjamin Franklin and Edgar Allan Poe, the American literary tradition seemed to begin with the so-called American Renaissance. (If that were so, of course, the term would really be a misnomer; how can a beginning be a rebirth? But the term Renaissance, borrowed from the various Renaissances of Western Europe, is itself is a revealing indicator of the way in which a handful of mid-19th century writers were elevated to the status of literary giants.)

The writers of the American Renaissance, in the classic formulation of F. O. Mathiessen, were Ralph Waldo Emerson, Henry David Thoreau, Nathaniel Hawthorne, Herman Melville, and Walt Whitman. Building on the achievements of these literary Founding Fathers in the later $19^{\text {th }}$ century were figures like Mark Twain, Henry James, and Stephen Crane. I don't recall, as an undergraduate, reading — or even being aware of - Emily Dickinson, now considered one of the major American poets of her century. Indeed, I don't recall studying any pre-twentieth century women writers - with the exception of Harriet Beecher Stowe, author of Uncle Tom's Cabin. In reading twentieth-century literature, I read no Edith Wharton, nor Kate Chopin, nor Edna Ferber, nor Willa Cather. Among African American writers, I read only Richard Wright and Ralph Ellison, I believe - not Frederick Douglass, Booker T. Washington, W.E.B. Dubois, Paul Lawrence Dunbar, or Langston Hughes, much less Zora Neale Hurston.

We rarely used anthologies, except perhaps in poetry courses, and I don't recall that the term canon was ever used. Still, the narrow range of writers taught to us gave us a sense of a canon - a list of accepted or sanctioned works. Indeed, to complete our majors, in addition to course work, we had to pass written comprehensive exams, which were based on a list of works issued from on high - no substitutions or alternatives were allowed. My undergraduate experience may not have been entirely typical of my generation, but I did attend Dartmouth College, one of the prestigious Ivy League institutions, so the curriculum should have been up to date. I should add, however, that, like many private liberal arts colleges, Dartmouth was then still a single-sex college with a largely, though not exclusively, white male faculty; those factors no doubt have something to do with the nature of the canon I studied.

Let's fast-forward to the semiprofessional stage of my education, when I took my Ph.D. in American Civilization, at Brown University (another Ivy League University) in the mid-nineteen-seventies. In that short interval, a great deal had changed. The women novelists of the nineteenth century were being rediscovered, so we read writers such as Mary Wilkins Freeman, Sarah Orne Jewett, and Kate Chopin. Edith Wharton stood beside Henry James. Emily Dickinson was enshrined next to Whitman as the other great American 
19th-century poet. She even had courses devoted exclusively to her. In the gap of four years or so between the end of my undergraduate education in 1968 and the beginning of my graduate work in the 1970s, then, the ground had shifted dramatically. It was no longer so clear who was canonical and why; the grounds of canonization were being challenged; everything seemed to be in flux.

Let's skip forward again, over more than a decade of continuing revision - to the professional stage of my career in the present. In most American universities, the basic introduction to American literature is the socalled survey course, which is a two-semester course using a two-volume anthology as its textbook. The revised canon is best embodied today in the Heath Anthology of American Literature, whose first edition was published in 1990 and whose second edition is forthcoming. The Heath is, as we say, at the cutting edge; it represents the most deliberate and extreme revision of the canon.

One can see that it is a revised canon even without opening the book to inspect its contents. Its size suggests its radical inclusivity. In number of pages it is fully fifty percent longer than most of its more modest and conservative competitors. The competitors have about 2,000 pages per volume; the Heath has about 3,000. In a not wholly successful attempt to keep it manageable in size, the pages were made thinner — so thin you really don't have to turn one to read the next; the print shows right through. Despite the tissue-thin pages, one can barely lift this book off a desk. Whatever its virtues as an anthology - and they are many - as an object it is somewhat repellent. It is bulky, it is heavy, it is clumsy. Because of its impractical size, it makes a better reference work than an undergraduate anthology.

But what about its contents? How does this canon differ from those I studied as an undergraduate and then a graduate student? One way of dramatizing its revisionary nature is to say this new anthology contains texts I did not know existed before I found them in it. It might embarrass me to admit this, except for the fact that most of these unfamiliar texts were from the colonial period, which is not my specialty. Moreover, many were not written in English. To say that the Heath is more multicultural than other anthologies is an understatement. Whereas conservative anthologies emphasize in the colonial period the writings of the prolific Puritans of New England - and thus establish as the progenitors of the canon writers who were White Anglo Saxon Protestants - the Heath reminds us of the various other cultures vying for power in the New World in the colonial and later eras. The new canon, then, attends to the French and especially the Spanish presence in North America; it also attends to the literary traditions of the indigenous people and of the Africans imported to work as slaves. The result is that the traditional major writers that I mentioned earlier have been joined and jostled by writers hitherto obscure or invisible.

When I proudly received my doctorate in 1977, I felt I had a reasonable command of the American literary tradition, certainly sufficient to 
begin a career as a college professor. I expected to do a good deal of additional reading in various writers as my career progressed, but essentially I thought I knew who the important writers were; it was just a matter of time and opportunity until I got around to filling known gaps in my preparation. But now, less than twenty years later, I find myself teaching texts and writers that I never even heard of as an undergraduate and in some cases as a graduate student. Like the universe, the canon seems to be steadily expanding in every direction, sometimes at a dizzying rate. Certainly, the canon threatens to expand faster than any of us can keep up.

One not altogether welcome result of this is that, whereas thirty years ago one might have professed American literature confidently on the basis of familiarity with a limited number of major writers, now the canon is too large for any single individual to claim mastery of — let alone for undergraduates to survey in two semesters. Exciting as this process is to some, it is demoralizing to others. The source of one objection to canon revision begins to be evident; while the project of revision creates a good deal of opportunity for new scholarly and critical work, it is somewhat unsettling - perhaps especially to older scholars — in that it threatens to undermine professorial competence.

So far, I have been treating canon revision as essentially a process of steady — if accelerating - expansion of a list of sanctioned writers or texts. Of course, the process is a good deal more complicated than that. Canon revision has two complementary aspects, and both are controversial. The one I have been emphasizing is what we might call its positive aspect: the addition of texts hitherto ignored or marginalized, texts not previously considered worthy of anthologizing, much less teaching. This positive activity requires, first, the discovery of forgotten writers; then, their critical recuperation or rehabilitation. It's not a simple matter of finding overlooked gems - texts that will immediately be recognized as worthy by all fair judges — despite their having been somehow lost in the shuffle. Rather, it involves redefining literary value to accommodate works written in different cultural circumstances, perhaps with different goals and aesthetic values than those works already in the canon. (Indeed, one of the major accommodations has been to recognize as literature what was never written at all - the oral compositions of indigenous and folk cultures.)

Let me offer some examples. When I was an undergraduate, the prevailing theories of American fiction focused on narratives about epic journeys away from civilization - often involving a special bond between two male characters of different races - as in Cooper's Last of the Mohicans (Natty Bumppo and Chingachgook), Melville's Moby Dick (Ishmael and Queequeg), and Twain's Huckleberry Finn (Huck and Jim). Recently, however, feminist critics have pointed out what a narrow set of criteria and texts were used to establish such romances as the dominant mode of American fiction. Those same critics have pointed out that, in devising their theories, critics like Richard Chase and Leslie Fiedler privileged a sort of 
experience denied most 19th-century American women. Feminist critics have reexamined the sentimental novel, which takes as its setting the middle-class household - precisely the world spurned by Melville and his peers. And they have argued that by a different aesthetic, these works have lasting significance. (In particular, Jane Tompkins's Sensational Designs has made this case.)

In my own specialty, autobiography studies, a fascinating instance of recuperation is found in the case of Harriet Jacobs. Long after the recognition of slave narrative as an original American literary genre, her pseudonymous narrative was excluded from serious consideration. Its pseudonymity, the role of the novelist and reformer Lydia Maria Child in its composition, and its reliance on some conventions of domestic novels led scholars to dismiss it as doubly corrupt - not wholly by Jacobs and not entirely nonfiction. The most dramatic - some would say melodramatic - aspect of the narrative is its account of the narrator's being hidden and confined - after her escape from a sexually predatory master - in a crawl space above the ceiling in a house in her home town, where she lingered to stay in touch with her children.

In the early 1980s, a curious and energetic scholar, Jean Fagan Yellin, undertook to investigate the circumstances of Jacobs's life and her writing of her narrative under the pseudonym Linda Brent. To make a long detective story short, she was able to verify many of the seemingly implausible details of the narrative. (In fact, she found the actual garret in which Jacobs was secreted from her pursuing master; the scholarly edition published by Harvard University Press contains maps of the town and diagrams of the house.) She also was able to establish that Child's role in the production of the book was minor, and thus that the text was the authentic expression of a self-educated former slave. The larger point is that the muchbelated authentication of Jacobs' narrative valorizes a distinctive female version of the slave narrative. Whereas the plot of male slave narratives emphasizes confrontation and physical escape to freedom, Jacobs revels in evading her master and continuing to mother her children, at the expense of a physical confinement that literally crippled her.

To canonize a writer, then, is not as simple as canonizing a saint. It is not just a matter of matching a rediscovered text to clear standards already in place; it may involve questioning and revising the standards used previously, which served to exclude these very works. Concurrent with this, however, and really inseparable from it, is the negative aspect of canon revision, the demotion of writers hitherto considered canonical. This follows necessarily from the positive activity, which, as we have seen, requires the development and application of new standards for canonization. Those revised standards may not be so favorable to the writers canonized under a previous set of standards.

As my examples have suggested, I hope, the most sustained and powerful instance of revisionism has been the feminist critique of the once male-dominated canon. One of the most powerful forces behind canon 
revision, the - probably the most important force - has been the women's movement. One manifestation of this has been the creation of a much more integrated university professoriate or faculty. Let me put this development in perspective by citing my own experience: I had not one female professor as an undergraduate or even as a graduate student. This was not because I avoided them; there were virtually none to avoid. In contrast, today, I have many female colleagues; middle-class women of my generation, the baby boom generation, were among the first to profit from the opening up of the professions to women.

Women have not just joined the university faculty, of course; they have greatly changed it. In literature faculties, one of the great projects of feminist critics has been to rehabilitate and add to the canon ignored women writers. At the same time, feminism has provided new critical perspectives from which some canonical male writers have been found wanting. Hemingway comes to mind as someone whose very identity as a writer is associated with a kind of masculinism that attracted early feminist critique. (But in Hemingway's case, at least, a very interesting thing has happened. When I first read Hemingway in college, his value system was not seen as male but as modernist; his wounded, disillusioned heroes and his minimalist style were seen as distinctive of the modernist aesthetic. By the time I got to graduate school, the feminist critique had begun to devalue his work precisely because it was male in all the wrong senses - devoted to violence, suspicious of women, and so on. Now, however, many gender critics are taking a much more complicated view of Hemingway, seeing in him much uncertainty and ambiguity about gender roles. Hemingway is rehabilitated as a postmodernist contemporary confused about gender. ${ }^{1}$ )

It is clear, then, that the new canon is not just larger and more inclusive than the old. The revised canon tends to include not merely additional individual writers but writers from groups hitherto excluded. The implication of their inclusion is that their exclusion - their marginalization - was in part a function of their membership in those classes. Few, if any, see this as a matter of a conspiracy on the part of the original canon-makers to exclude women and other minorities as different and therefore inferior. Rather, the argument is that canon-formers understandably but regrettably generalized from their own experience; they saw male experience as universal, but their literary values were covertly biased toward writers of their own gender. If feminists argue that sexism - conscious or otherwise historically undervalued the work of women writers, then it should come as no surprise that feminist efforts to promote new writers - often women and to demote others — usually men — will meet with resistance. And similarly with other marginalized groups.

\footnotetext{
${ }^{1}$ See for example, Hemingway's Genders: Rereading the Hemingway Text, by Nancy R. Comley and Robert Scholes.
} 
It is now time to face more directly the politics of canon revision. For canon revision is not a matter of the gradual rise and fall in the stock of individual writers already in the canon (the literary Dow-Jones, as it were) Gertrude Stein is up 1/4, Fitzgerald is down 1/2. To use another analogy, perhaps more apt, we are not talking about incidental and unconnected changes in the membership of an exclusive club; so-and-so is admitted, soand-so is expelled - upsetting as such changes might be to partisans. For we are not discussing the addition and substraction of members from the same pool of applicants - the same gene and gender pool, as it were. Rather, by canon revision we mean a concerted attempt to redefine literary value and to reevaluate the very grounds for membership. Thus, to repeat, canon revision involves the addition of writers from entire categories or pools hitherto excluded. (It is, then, related to the women's movement, the civil rights movement, the coming to power, political and cultural or once oppressed groups. And today, of course, it resonates with and raises the same issues as affirmative action, the federal policy that gives a slight but significant advantage, in certain circumstances, to members of historically oppressed groups.)

For reasons I have hinted at - the need to redefine literary standards - canon revision means not just the admission of different groups of writers but also of different kinds of writing to the canon - genres such as slave narrative, diary, songs, and oral tales. (One anomaly of the process is the canonization of writers who couldn't write, and who may be listed in tables of contents by the same name: anonymous.) The controversy over these changes to the canon has been bitter at times; indeed, we might think of canon revision as one front in what we call the culture wars - the ongoing struggle over the values encoded in official culture. (Other fronts would be the disputes over censorship of the arts, the rights of homosexuals, over the status of the English language. And while the term culture wars is used quite casually, let me point out that it is not always figurative or metaphorical; like real wars, the culture wars sometimes involve physical violence, even killing - as has recently been the case in the controversy over abortion in the United States.)

We may put the controversy over the recent rapid and dramatic revision of the canon of United States literature in a helpful perspective, I think, if we remind ourselves where the term canon comes from, because its original context supplies it with crucial connotations. The term canon, of course, was appropriated for literary studies from religious studies, where its relevant sense is the collection of texts regarded as Scripture - that is, as sacred, holy, authoritative because they are divine in origin, inspiration, or authorship. To borrow the term for a set of literary texts was in effect to use it metaphorically, applying it to a set of texts that lack divine authority but that are endowed, in part by the very application of the term, with a kind of aura of authority, a mystique of value, a sense that they are virtually above criticism (in the sense of negative evaluation). 
The important thing to see at this point is that the transfer of this term from one context to another is itself an important act of mystification of the canon - the attribution of a sort of authority to literary texts that, by definition, they cannot have - a sort of other-worldly, or divine, sanction. In the crossover from the sacred to the secular, the passing off of a set of literary texts as analogous with a set of religious texts, there is a kind of sleight of hand. One root of controversy over canon revision may lie in the received sense of a literary tradition as somehow sacrosanct, having a kind of transcendent or transhistorical value.

When we reflect on this, we can begin to see why canon revision meets such resistance in some quarters. For we can imagine the controversy that would arise if someone were to challenge the Scriptural canon - to try, for example, to expel one of the gospels from the New Testament. In fact, we do not have to imagine what would happen; we only have to remind ourselves of the tensions and violence in the past and present between groups that disagree over what constitutes scripture. For although I have been using the term canon in the singular, and though it is, I believe, a term that originates with the Judaeo-Christian tradition, we know that even within that context, the term canon has no single referent. The term Bible is itself radically ambiguous; there is no single set of texts to which it refers. I am not referring to the difference between different versions, such as the classic King James version and more modern ones, or to differences between translations, much less issues of interpretation - liberal or literal — although those seemingly minor differences themselves have fueled controversies. Rather, I am referring to simple disagreements over which texts count as scripture in the Judaeo-Christian tradition - differences between Jews and Christians, and between Protestants and Catholics. For one's membership in a particular religious community is in large part a function of which texts one regards as sacred.

We need to remind ourselves of an intrinsic and critical difference between literary and religious canons. Religious canons are generally considered to be complete, coherent, and closed, decided for all time; hence the obstacles faced by those who wish to establish new texts as scripture ${ }^{2}$. Consider the example of Mormonism, founded in the nineteenth century, and the Church of Scientology, founded the twentieth. The more recent in origin the scripture under consideration, the harder it is to convince others of their canonical status. (Which is why new scriptures are usually passed off as ancient texts newly revealed or discovered.)

In contrast, literary canons are openended, even in the view of conservatives. As time passes, new works are continually being created, and eventually some are added to the canon. A literary canon necessarily loses

\footnotetext{
${ }^{2}$ And as Alastair Fowler reminds us, even the "biblical canon was arrived at only after many vicissitudes and over a period of many centuries. At each stage it was categorically fixed; but when it enlarged of contracted, the new canon, too was definitive". "Genre and the Literary Canon", New Literary History, 11.1 (Autumn 1979): 98.
} 
definition in the recent past and just trails off in the present. It is expected to be extended indefinitely as long as the language and culture survive. Indeed, such expansion may be crucial to its continued vitality; a literary canon with a closed end would seem to indicate the death of the language or culture.

It is in the present, then, that the process of canon formation is most visible, its workings most transparent. Let me revert again to autobiography to make this point. In my final term as an undergraduate, in 1968, I took a popular course in Twentieth Century American Fiction. The course ended, very dramatically, with In Cold Blood, then quite new and very controversial. (The book, which may be unfamiliar, was Truman Capote's novelistic account of the actual murder of a middle-class Kansas family, by a pair of drifters who were later caught, convicted, and executed.) It was controversial for two major reasons. One was that, having interviewed the murderers extensively in prison, Capote grew very fond of them; some felt the resulting narrative romanticized them and their brutal crime. (Given the treatment of crime and violence in American literature and film today, of course, such a complaint seems rather quaint.)

The other had to do with the book's generic status. Presented under the paradoxical label of nonfiction novel - a true story using fictional techniques - it seemed to question the very distinction on which that literature course was built — the distinction between the factual and journalistic, on the one hand, and the fictional and imaginative on the other - indeed, between the non - or subliterary and the literary. In its modest way, that course helped to undermine our sense of the canon, because whether In Cold Blood was literature at all, much less whether it would prove a classic, was very much the point of its being offered to us. So whereas the early twentieth-century works in that course were presented to us as definitely and undeniably canonical, the course, by ending as it did with a controversial contemporary text, enabled and encouraged us to see that the canon is always in flux at its near end.

An American politician once quipped that making laws is like making sausage; the process is so messy, even disgusting, when seen up close, that exposure to it may cost us our taste for the endproduct. (This is an argument for not broadcasting the proceedings of legislatures on TV.) It is in the present that we can see most clearly the crucial gap between the religious and the literary canons. There is no clear or explicit set of rules or criteria; there are no official judges for the process of canon formation. Moreover, in the present, we necessarily lack the sort of hindsight that the sense of a canon presumes; we cannot say of contemporary literature that it has passed the test of time. To look carefully into the process at this juncture is to become aware of its messiness - its contingency and instability — and it is precisely this, a close examination of the process, that has led to the demystification of the literary canon in my lifetime.

As I have suggested, even the most conservative of observers would not argue that the literary canon is never subject to change. What 
conservatives complain about is not that the canon has been changed but that it has been revised - that is deliberately and programmatically changed; in the view of conservatives, judgments of canonicity, traditionally and properly made on purely literary grounds, have become politicized. What they mean by that is that certain groups new to the academy — such as women and African Americans - have promoted, in a kind of power play, works written by their own members - that works by previously marginalized groups have been added to the canon on political grounds for political motives; diversity has been achieved for the sake of diversity. Literary quality has been lost sight of.

It is undeniable that the integration of new groups into the professoriate has coincided with and impelled canon revision; it is also undeniable that, for example, female critics have recuperated women writers and critiqued male writers. What is debatable is whether this is a politicization of a hitherto neutral or apolitical process or a function of the recognition that the canon was always political.

What the revisionists argue is that the process was never not political. The old standards, which conservatives claim were literary rather than political, were always inevitably inflected to a degree by gender, race, class, and ideology. The exercise of aesthetic standards - no matter how rarefied - is always an exercise of cultural power and, in that sense, political. One does not have to see a conspiracy on the part of male critics to exclude women writers to see that the traditional canon was biased toward men. What they considered of universal interest and timeless in value was, unbeknownst to them, appealing partly because it spoke to their experience. We all have a tendency to regard our own experience and values as universal, but it was white male critics who happened to be in the position of being able to make their judgments stick.

In the case of literature, it is because the canon is now seen as having unfairly privileged the elite groups who defined it, that so much energy has gone into challenging and revising it. One explicit - and undeniably political - motive has been to make the canon more reflective of minority experience. If the old canon tended to be monolithic and mono-cultural, the new revised canon tends to be multicultural and, to some extent, to be about multiculturalism; that is, it tends not only to include women writers and writers of color, as we now say - but to play off their writing against that of writers from the mainstream. The revised canon, then, differs from the old not only in being larger and more inclusive, nor only in being more colorful and multicultural, but in its paradigm. The old paradigm of the American literary tradition was a teleological one; survey courses offered a meta-narrative of the development of an American literature of world-class quality. The new paradigm is different, one in which various distinctive traditions are braided, not blended together. Or to put it differently, one in which culturally distinct groups may speak back to one another, interrogating and answering each others' discourse. The old paradigm is a monocultural monologue; the new model is a multicultural dialogue. 
This also troubles conservative critics, who charge that a healthy cultural consensus - the ideal of the melting pot - has been fractured, that the recognition of multiple cultures within United States - that of women, of African Americans, of Hispanic Americans, etc. - threatens cultural cohesion and national unity. In contrast, critics on the left see a monocultural canon as repressive of cultural difference, reenacting or reinforcing the oppression of minority groups. What critics on the right see as unAmerican and unpatriotic, critics on the left see as liberatory, and potentially redemptive.

In ending this account of canon revision in the U.S., I want to offer three modest and moderating suggestions. The first is that, in view of the demystification of the process of canon formation, we accept that literary canons are inevitably partial, in two senses. They are partial in the sense of being incomplete; they can never include all the writing of value. And they are partial in the sense of being biased; they are inevitably rooted in various culturally biased preferences and prejudices. These can be corrected for over time, but they can never be wholly eliminated.

My second suggestion follows from my first: it is that we think of the canon, somewhat paradoxically, as those texts that are temporarily thought to be of permanent value. We should of course attempt to canonize texts that speak, and will continue to speak, to those outside their immediate cultural contexts; those are the ones that have passed the test of time. At the same time, we need to recognize that the process of canonization is always implicated in its own cultural context - not transcendent of it. Thus, the anointment it conveys is always contingent and may prove short-lived. The canon has always been and will always be in the process of being formed and reformed.

My final suggestion is that we might reconceive the term canon itself, by reference to a relatively obscure and specialized meaning of that word $^{3}$. In the language of Western music, a canon is a piece written in counterpoint, in which different voices create an overall effect of intricacy, order, and harmony - precisely by moving against one another in different directions and at different speeds. (It has a similar meaning in the terminology of dance.) We might think of the American literary canon as an extended musical piece in progress; integral to its overall beauty and power is the presence of distinct voices in different registers.

\section{BIBLIOGRAPHY}

\footnotetext{
${ }^{3}$ Of course, there are those who would abolish canons altogether. But this is not as easy a it seems. The very processes of teaching and criticism require some selectivity; in practice, they tend to canonize certain works.
} 
CHASE, Richard. The American novel and its tradition. Baltimore, Johns Hopkins University Press, 1957.

COMLEY, Nancy R.; SCHOLES, Robert. Hemingway's genders: rereading the Hemingway text. New Haven, Yale University Press, 1994.

FIEDLER, Leslie. Love and death in the American novel. New York, Criterion Books, 1960.

LAUTER, Paul, ed. The heath anthology of American literature. Lexington, MA, D. C. Heath, 1990.

JACOBS, Harriet. Incidents in the life of a slave girl, written by herself. Ed. Jean Fagan Yellin. Cambridge, Harvard University Press, 1987.

TOMPKINS, Jane. Sensational designs: the cultural work of American fiction, 1790-1860. New York, Oxford University Press, 1985. 